\title{
Deforestation / Reforestation in Mediterranean Europe: The Case of Greece
}

\author{
Olga G. Christopoulou \\ University of Thessaly \\ Greece
}

\section{Introduction}

Forests perform multiple and interrelated social, economic and environmental functions and can be comprised among the ecosystems with the greatest biodiversity. The contribution of forests is multiple and renewable and, therefore, they constitute a most valuable natural resource.

The benefits / values of forests can be divided into those of direct and indirect use. The first category includes the value of timber, which is used, on one hand, in shipbuilding and, on the other hand, in supporting a great chain of industries such as construction, furniture manufacture, printing and packaging. The forestry sector provides about $8 \%$ of the total manufacture added value. Forest feedstock, goods and services can also provide important background for the economic reinforcement and green development in the countryside. The primary wood industry offers sawn wood, fibreboard, particleboard, pulpwood, fuelwood as well as wood chips and bark for bioenergy, in fact it employs more than 2 million people and it often involves small or medium enterprises in rural areas (Confederation of European Forest Owners).

Apart from wood, which constitutes the main forest product, forest ecosystems provide a range of products of economic value such as bark, resin, honey, small berries, aromatic leaves (laurel), mushrooms, medicinal herbs, game, forage material etc. The value of forest biodiversity can not be ignored. Forests serve not only as shelter of flora and fauna, but also as a valuable natural gene pool. The value of information deriving from forest biodiversity for pharmaceutical use is subject to ongoing scientific research.

Recreational, aesthetic and health effects of forests can also be placed among their economic and socio-cultural values of immediate use. Forests, with their great surface, are the only part of every country that is free from pollution sources, while forest light, with its low intensity and high content in green radiation, has a soothing effect on the nervous system. For these reasons, forest-tourism, a specific form of tourism, is being developed which can be combined with walking tourism and ecotourism, and is a constantly developing category of mild and environmentally friendly tourism. Forests that are being managed for recreational purposes raise the value of neighbouring properties (Pearce 2001) and encourage tourism. Moreover, employment, particularly for populations who live near the forests and the exploitation of forest energy sources to produce soft forms of energy (biomass) can be added to the long list of benefits from forests. 
The hydrologic function of forests, including protection against soil erosion, prevention of flooding while protecting settlements and infrastructure, a significant reduction in flood peaks, enrichment of underground aquifers and a contribution to the quality of water from an chemical and microbiological point of view, can be placed among the benefits and indirect use values of environmental character of forests.

The forest also has many environmental functions: it provides wind protection, protection from noise, and has an impact on climatic factors (light intensity and quality, mitigation of extreme summer and winter temperatures, air humidity).

Special attention should be paid to the key contribution of forests to the oxygen cycle, to absorption carbon dioxide and to air de-pollution (with physio-mechanical and biochemical means), also taking into account the context of climate change. According to the Global Organisation of Food and Agriculture, the world's forests store more than 650 billion tons of carbon ( $44 \%$ in their biomass, $11 \%$ in dead wood and litter and $45 \%$ in forest soil). Whereas, according to data from Eurostat (2009), at least 9.580 million tons of carbon have been stored in biomass in the forests of the EU of 27, without taking into account the amount absorbed by the dead biomass or forest soils.

Forests along with the oceans comprise the main mechanisms that regulate the balance the equilibrium of the $\mathrm{CO}_{2}$ cycle. A hectare of forest of average productivity processes, each year, 10-12 million cubic meters of air to retain at least four tons of $\mathrm{CO}_{2}$. Thus, it contributes significantly to maintaining / improving atmosphere quality both as a $\mathrm{CO}_{2}$ consumer, as much as an $\mathrm{O}_{2}$ producer. Concern for increased $\mathrm{CO}_{2}$ and its implications on climate change is plausible, however, a truly significant problem, arises from the fact that the largest feedback mechanisms for regulating $\mathrm{CO}_{2}$, such as forests and oceans, are losing their regulatory capacity due to deforestation $(2 / 3$ of forests worldwide have already been destroyed) and marine pollution.

The above mentioned complex values of forests demonstrate the imperative need to protect and preserve them.

\section{Condition of forests globally and in Europe}

At a global level, forests cover $30.3 \%$ of the total surface of the earth, meaning that $0.62 \mathrm{Ha}$ of forest correspond to each inhabitant of the earth. More than half of the forested areas belong to the Federal Government of Russia (Russian Federation), Brazil, USA, Canada and China (FAO, 2005).

Regarding the European Union, forests cover an area of 177 million hectares or $42 \%$ of its total area. The countries with the largest forest coverage are Finland (77\%) and Sweden (75\%), followed by Spain (57\%), Italy (37\%), Germany (32\%) and France (31\%). The countries with the smallest forest coverage are Malta (1\%), Ireland $(10 \%)$, Holland $(11 \%)$ and the United Kingdom (12\%). In the territory of the united Europe about $4 \%$ of the world's forests are located, but, average forest land corresponding to each European resident is small (0.36 $\mathrm{Ha}$ ), due to increased population density. However, forest land per capita varies from 4.4 $\mathrm{Ha}$ (Finland) to $0.07 \mathrm{Ha}$ (Belgium) (Eurostat, 2010).

Between the years 2000 and 2005, forest coverage in the EU increased by $1.6 \%$, a fact that can be attributed not to a cease of pressure on forests, but mainly to the abandonment and consequential afforestation of agricultural land and to the abandonment of mountain summer pastures.

While, at global level, deforestation has decreased, however, the conversion of tropical forests to agricultural land, in some countries, continues and at an alarming pace too. 
Overall, 13 million Ha of forest land per year were being attributed to other uses or destroyed by natural causes during the decade 2000-2010, while during the decade 19902000, the corresponding forest land was 16 million Ha / year. On the other hand, the creation of new forests, protection programs of the landscape and natural expansion of forests reduce this loss. For instance, the net modification in forest land for the years 2000-05 was -7.3 billion $\mathrm{Ha} /$ year. (FAO, 2005)

In the Caribbean, Europe, North America and Oceania, most countries do not present significant changes in their forest lands, whereas, in Africa and South America, the majority of countries are presenting significant losses in forest land.

During the decade 2000-2010, the six countries that presented the highest rates of forest land loss were Nigeria, Zimbabwe, Myanmar, Indonesia, Brazil and Venezuela. Correspondingly, the six countries that produced the largest growth rates of their forest land were Viet-nam, China, Turkey, Italy, Norway, Spain and India. The increase of forest land in these countries can be attributed mainly to the afforestation programs (China has proceeded to a large-scale afforestation) and to the natural expansion of forests. Agriculture is considered to be the main cause of afforestation. In the logic of "slush and burn" agriculture, farmers cut down and burn trees in order to produce farm lands or stockbreeding lands (FAO, 2005). Forest insects and diseases are a major threat to the forests of the world, particularly in temperate and northern forests (e.g. beetle Dendroctonus ponderoseae, wiped out more than 11 million hectares in Canada and the western United States of America since late 1990), however, they affect less than $2 \%$ of forests at a global level (FAO, 2010). Finally, fires affect not only forest cover and the subsequent reduction of carbon accumulation, the protection from soil erosion and, generally, the reduction of all functions and services of the forest, but they also release into the atmosphere large quantities of greenhouse gases. Naturally, certain types of forest ecosystems are adapted to natural fire (eg in Mediterranean ecosystems), but, very often, a fire can get out of control, or torrential rains may follow immediately after the fire leading to soil erosion and simultaneous loss of seeds (eg of the Mediterranean Pinus halepensis). Globally, forests affected by fire contribute for $1 \%$ of the total annually, taking into consideration that several countries, particularly in Africa, do not record forest lands hit by fires.

Therefore, overall, global carbon capture is decreasing as a result to a forest land loss tendency.

\section{Current state of forests in Greece}

The first systematic effort to record Greek forests was made by the Forest Service via the "First National Forest Inventory" that started in 1963 and ended in 1992. The inventory data cover important quantitative aspects of forests, allocated geographically by county, catchment basin and forestry. However, qualitative data, on one hand concerning the trees and on the other hand the entire forest ecosystem, are not adequately covered.

Therefore, according to this first national inventory of Greek forests, land uses in Greece, were as shown in Table 1.

\begin{tabular}{|l|c|}
\hline Land uses & \% of the total expanse of the country \\
\hline Forests & 19.0 \\
\hline Forestlands - Pastures & 43.3 \\
\hline Agricultural crops & 30.0 \\
\hline Settlements, arid areas, rocks & 5.6 \\
\hline Lakes, rivers, marshes & 2.1 \\
\hline
\end{tabular}

Table 1. Land uses according to the first inventory of Greek forests 
However, the inventory of 1981 produced different results presented in Table 2.

\begin{tabular}{|l|c|}
\hline Land uses & \% of the total expanse of the country \\
\hline Forests & 22.4 \\
\hline Forestlands - Rangelands & 39.8 \\
\hline Agricultural crops & 29.90 \\
\hline Settlements, arid areas, rocks & 5.60 \\
\hline Lakes, rivers, marshes & 2.30 \\
\hline
\end{tabular}

Table 2. Land uses according to the inventory of 1981

From the above tables, it becomes evident that the land of Greek forests has increased by $3.4 \%$, whereas today, the land occupied by forests (industrial forest) contributes for $25.4 \%$ of the total country land, thus, overall, Greek forests have increased by $6.4 \%$ since the first forest inventory.

The composition of Greek forest according to species can be observed in Table 3 below (Ministry of Environment, Energy and Climate Change / General Directorate for Development and Protection of Forests and Natural Environment, 2010).

\begin{tabular}{|c|c|c|}
\hline Tree species & Land (Ha) & Percentage $\%$ \\
\hline A. Coniferous & & 13.1 \\
\hline Abies-Picea abies & $3,297.62$ & 18.9 \\
\hline Pinus halepensis-brutia & $4,757.77$ & 5.5 \\
\hline Pinus nigra & $1,370.47$ & 0.9 \\
\hline other Coniferus & 237.87 & $\mathbf{3 8 . 4}$ \\
\hline Total Coniferus & $\mathbf{9 , 6 6 3 . 7 3}$ & 29.8 \\
\hline B. Broadleaved & & 8.7 \\
\hline Quercus & $7,475.49$ & 4.1 \\
\hline Fagus & $2,190.70$ & 19 \\
\hline other Broadleaved & $1,017.65$ & $\mathbf{6 1 . 6}$ \\
\hline maquis & $4,776.61$ & $\mathbf{1 0 0}$ \\
\hline Total Broadleaved & $\mathbf{1 5 , 4 6 0 . 4 5}$ & $\mathbf{2 5 , 1 2 4 . 1 8}$ \\
\hline Total & & \\
\hline
\end{tabular}

Table 3. Forest cover according to tree species

Mediterranean evergreen sclerophyllous vegetation (maquis) is dominant, as demonstrated on the table, while the oak is a common species in Greek forests as well.

Regarding the ownership regime of Greek forests, the vast majority of them, as shown in Table 4 (Ministry of Environment, Energy and Climate Change / General Directorate for Development and Protection of Forests and Natural Environment, 2010) below, are public. The management of all Greek forests of different ownership regimes is subject to State control and management of all forests takes place based on the principle of sustainability of yields. However, there are cases of non-compliance with the principle, where extraction of higher woody mass than the one that ensures the productivity of the specific ecosystem takes place with the consequence of its gradual quantitative and qualitative degradation, which adversely affects the biodiversity of forest ecosystems, the future production of wood, the quality and quantity of water, the protection against soil erosion, the capture of carbon 
dioxide and, generally, all beneficial to humans functions of forests that have been mentioned above.

\begin{tabular}{|c|c|c|}
\hline Ownership type & Land (Ha) & Percentage $\mathbf{0}$ \\
\hline State forests & $1,644,005$ & 65.5 \\
\hline Municipal & 301,527 & 12.0 \\
\hline Monasterial & 109,946 & 4.4 \\
\hline Charitable Institutions & 11,225 & 0.4 \\
\hline Forests in public ownership & 245,845 & 9.7 \\
\hline Private & 199,870 & 8.0 \\
\hline Total Forests & $\mathbf{2 , 5 1 2 , 4 1 8}$ & $\mathbf{1 0 0 . 0}$ \\
\hline
\end{tabular}

Table 4. Type of Greek forests ownership

Greek forests according to their utility and functions can be divided into: a) Productive Forests which are important for the production of forest products or other goods of primary production, b) Protective forests, which might have special protective effects on soils and underground water, might also protect subjacent settlements, cultural monuments and structural works and facilities and c) Forests of special scientific, aesthetic, ecological or geomorphological interest, such as National Parks (10), Aesthetic Forests (19), conserved natural heritage sites or Recreation Forests that can be used for leisure or act as agents of tourism development.

Depending on their capacity to produce wood, they can be divided into Industrial Forests (covering 25.4\% of the country's land) which are capable of "producing $1 \mathrm{~m}^{3}$ of wood / $\mathrm{Ha} /$ year, as well as trees with trunks of cellulose wood (with a diameter) of at least 1, $2 \mathrm{~m}^{\prime \prime}$ and Nonindustrial Forests (covering 23.9\% of the land of the country) constituting of multibranched dwarf trees and shrubs which do not currently produce marketable timber products and are available for grazing, firewood and protection of catchment basins ( Ministry of Agriculture, 1992).

Depending on their management form, they can be divided into: high forests (34.7\%), whose regeneration, naturally or artificially, made with seeds or seedlings from seeds, coppice forests $(48 \%)$, whose revival originates from coppice sprouts for species that possess the ability to multiply in this way (oak, beech, chestnut, maquis) and are plainly anthropogenic and finally medium forests (17.3\%) (Kotoulas et al., 1989).

Finally, depending on the extent of human influence and the degree of deterioration caused by human intervention, forests are divided into Virgin or Natural, when anthropogenic disturbances have not influenced the natural development of the forest ecosystem (in Greece there is such a forest in Mount Rhodope) Semi-natural, where human intervention has affected the natural progression, however without making impossible its function and natural development, and Artificial or Plantations where forests result from human management actions that control their creation process and evolution.

Regarding the sanitary condition of Greek forests, it is strongly influenced by biotic (insects, fungi), as well as abiotic (drought, late frosts) factors. Up until today, there have been no signs of damage (defoliation / needle-fall), attributable to air pollution and acid rain in particular, although episodes of acid rain have been recorded (Oikonomou et al., 2004). 


\section{Deforestation / forest degradation}

According to the Working Document of the Commission of the European Communities, entitled "Addressing the challenges of deforestation and forest degradation to tackle climate change and biodiversity loss. Impact Assessment" (COM(2008) 645), deforestation is defined as "the conversion of forest land to another land use (or reduction under 10\% crown cover without change in land use)". Additionally, the term degradation is defined by the IPCC (Intergovernmental Panel on Climate Change) as "a direct human-induced loss of forest values (particularly carbon), likely to be characterised by a reduction of tree cover. Routine management from which crown cover will recover within the normal cycle of forest management operations is not included".

In the same text, the main direct causes of deforestation include: the change in land use due to the expansion of agriculture, mining and quarrying activities, infrastructure development (roads, electricity and water-supply systems etc.). (Chomitz and Gray 1996), and illegal or non sustainable logging. As indirect causes, we can report institutional issues such as governance issues (e.g. non-definited property rights), issues of spatial planning, policies that indirectly provide incentives for deforestation by subsidies in agriculture, urban expansion, infrastructure increase, etc.

Other causes that may lead to deforestation and / or degradation of forests may be related to the environment (e.g. soil quality, topography) (Kaimowitz and Angelsen, 1998), to biophysical factors (e.g. drought, fire) or social events (wars, revolutions, social upheavals, sudden movements, sudden political changes, economic shocks etc). The above, may be enhanced by the following factors: demographic factors (population density, natural population growth, migration, etc.), economic factors (e.g. market growth and commercialization, urbanization and industrialization), technological factors (e.g. in agriculture or in wood utilization), and cultural factors (such as attitudes, values, beliefs of societies and individual behavior in relation to forests).

Geist and Lambin (2001), mentioned three major causes of deforestation: the return of forest land to agriculture, timber extraction and the expansion of infrastructure. These interact with five primary indirect factors: the demographic, the economic, the technological, politics and cultural changes. Their study concludes that deforestation is best explained by a combination of direct and indirect causes: the construction of roads creates new access to forest land, forest protection and regulation of export activities is inadequate, forestlands can be converted for the needs of agriculture or, there may be a large inflow of immigrants due to demographic and poverty-related factors in the regions from which the immigrant waves originate from.

Inadequate logging practices that leave behind large amounts of combustible wastes make forests vulnerable to fires caused in order to clear land for agriculture, further degrading the forest.

According to Lambin et al., 2001, the most important phenomena of land use conversion concern forests and are related to forest fragmentation and transformation of forest land. The processes that incite this type of change are particularly complex and are due to a plethora of interactions between natural ecosystems and human demand for land use for many different purposes (Minetos and Polyzos, 2010) and relate to economic as well as social and environmental factors (Verburg et al., 2006). It should be noted that these factors or a combination of factors may be different for different countries and different time periods. 


\subsection{Deforestation in Greece}

According to the Greek Parliament (2003) in the explanatory report regarding the new Law on Forests, recent land use changes on forests and forest land in Greece are the result of complex economic and social processes that result in creating spatial patterns in which a decline in the forest component can be observed. This negative image is due to high growth rates, coupled with an inefficient and fragmented land planning and urban design legal framework (Rizos, 2004). In several areas, forests and forest lands take the greatest heat for the expansion of urbanization and of agricultural or livestock operations (Beriatos, 2002, Christopoulou et al., 2007). Particularly in southern Greece, the islands and much of continental lowland and upland areas, forests are gravely destabilized due to fires, overgrazing, widespread building out of the city plan, and the creation of traffic infrastructures (Minetos, 2009).

According, again, to Minetos (2009), who studied the changes in land use in the time period 1990-2000, the 'diffusion' of urban land uses outside city plans and settlements in Greece, has negatively affected forest lands. The phenomenon extends to areas that are relatively remote. On the contrary, no trends of extending rural uses to the detriment of forests, in counties designated by a dynamic agricultural sector, were found. Finally, tourism development in recent years, due to the institution of Environmental Impact Assessments, had limited effects on forest lands, except for some cases of intense tourism growth in out of city plan areas.

\subsubsection{Overgrazing}

Overgrazing occurs when the number of animals using a pasture is greater than the grazing capacity, assuming that the excess number of animals could range from a few to very many. Consequently, the number of animals kept in a pasture or grazing intensity is an important indicator of pasture degradation (Papanastasis, 1998; 2000). Grazing results in the deterioration of pastures leading to erosion and desertification of soils as well as in inadequate nutrition of livestock animals since they can not receive an adequate ration in a degraded pasture.

Since ancient times, grazing, mainly involving goats and sheep, can be viewed as one of the key factors of degradation in mountainous and upland (semi-mountainous) Mediterranean ecosystems. This is due to the large number of animals, the constant, throughout the year, grazing and the combination of stockbreeding with deforesting logging and fires for improving fit for pasture material (Greek Committee for Combating Desertification, 2000).

Mediterranean rangelands include pastures, as well as "forest" rangelands, namely low bushy land (e.g. phrygana, garrigues), shrubs (e.g. maquis) and sparse forests (tree cover less than 40 \%). According to Le Houerou (1981), these pastures are being grazed with a density of 2.2 sheep / Ha. Bearing in mind that the grazing capacity of Mediterranean rangelands cannot surpass 1 sheep / Ha, we conclude that Mediterranean pastures are being overgrazed.

In Greece, grazed forestlands (forest rangelands) cover $40 \%$ of the country. In these, the largest area is occupied by forests (48\%), followed by grasslands $(32.5 \%)$, shrublands $(15.1 \%)$ and finally phrygana (4.4\%). Grazed forests are estimated to stretch for about two million Ha. The proprietary rights of these areas belong, in the largest proportion (75\%), to the state and their use (occupancy) belongs to the municipalities and communities. The continuous and ongoing for many years overgrazing has led to deterioration of both the forage and soil (Ministry of Environment, Energy and Climate Change, 2010). 
This, naturally, is aided by the mild Mediterranean climate that contributes to grazing throughout the year, the xerothermic conditions in the summer, the peculiar ownership regime in combination with the lack of cadastre and the subsidies to animal breeders through CAP (until Agenda 2000 enters into force) depending on the number of animals.

A common practice for farmers in order to control unwanted vegetation, in different parts of Mediterranean Europe (e.g. Corsica, Sardinia, Crete, and Western Greece), is the use of fire. Although Mediterranean vegetation has adapted to these circumstances and usually regerminates, however, this may lead to desertification, if the fire is combined with overgrazing. Several studies have demonstrated that the combination of fires and overgrazing are the main cause of degradation and desertification of rangelands in Mediterranean Europe (Margaris and Koutsidou, 1998; Papanastasis et al., 1990).

Papanastasis (2008) reports that in a study on the impact of overgrazing on Mount Pseloretis in Crete, aerial photographs of the area, for the years 1961-1989, were analyzed and the major types of land uses were identified and recorded. The results demonstrated an increase in sparse and medium density brushlands (mainly ecosystems of phrygana), at the expense of high-density areas, as well as forests. This course indicates land degradation as fewer shrubs account for less forest plant coverage for soil protection and the support of its productivity. The consequences of overgrazing were greatest when it was combined with deliberate rangeland fires.

\subsubsection{Fires}

Forest fires are part of the ecology of Mediterranean ecosystems and could not be eliminated even through the development and implementation of the perfect fire management planning (Xanthopoulos, 1998). They are to some extent an inevitable ecological phenomenon that can also be caused by physical factors (eg, thunderbolt, spontaneous combustion). For this reason, Mediterranean ecosystems have developed adaptations to natural fires that allow them to be renewed after a fire. Such adjustments are the resprouting capacity of maquis, when their surface part is burned, as well as the opening of the Mediterranean conifer cones to release seeds (e.g. Pinus halepensis).

But when the frequency of fires in this zone increases due to anthropogenic agents (arsons), then the natural process and balance becomes diverted, resulting in degradation of forest ecosystems. When repeated fires are combined with overgrazing, the consequences are irreversible and lead to desertification. In the last decades, despite an increase in personnel and engineering resources, fires are getting increasingly destructive, (Tambakis and Karanikola, 2002).

The causes of forest fires in Greece are complex and interrelated.

a. Natural Causes

Thunderbolt is a well known and very old natural cause of fires. It should be noted that in Alberta, Canada it has been established that $81.1 \%$ of the burned surface in large (over 200 $\mathrm{Ha}$ ) fires originated from lightning strikes. In Greece, thunderbolt is culpable for $2.2 \%$ of forest fires. Additionally, spontaneous combustion of flammable ecosystems (forests with a thick layer of dry pineneedles) has been recorded as a possible cause of fire (Kailidis and Karanikola, 2004).

Therefore, the view supporting that fires are an eco-factor is valid for only $2 \%$ of forest fires (Zagas et al., 1998). 
b. Anthropogenic Causes

B. Unknown

Unknown causes account for $35 \%$ of all causes of forest fires according to the Ministry of Agriculture (2005) or for $25.7 \%$ according to Kailidis and Karanikola (2004). Sparks originating from cars, trains, chain saws, farm machinery or even live wire from the Public Enterprise of Electricity may constitute random / unknown anthropogenic causes of fire outbreaks, as reported by foresters (Kailidis and Karanikola, 2004). Broken and discarded glass bottles exposed to high temperatures (summer afternoons) or mineral bottles of aerosols can start a fire in litter or in forests.

$\mathrm{B}_{2}$ Negligence

Human negligence also constitutes 35\% of the causes of forest fires for the time period 19902004 (Ministry of Agriculture, 2005), whereas Kailidis and Karanikolas (2004), attribute $42.8 \%$ of all fires to negligence. Negligence is considered to be the extension of fires from burning stubble, burning dry branches and grass in fields and gardens, disposing lit cigarettes or matches $(10.7 \%$ of events) and garbage burning $(6 \%)$. The burning of crop residues is prohibited by the EU and compliance with environmental conditions is a prerequisite for the granting of subsidies to farmers. Regarding the latter cause, it is expected to decline significantly, since shutting down all uncontrolled waste disposal sites (landfills) and replacing them with sanitary landfills has been imposed by the government. Easy access to forests by all people, due to the opening of several kilometers of forest roads, and recreational activities in forests (e.g. use of fire for picnics) can become the cause of fire by negligence.

$\mathrm{B}_{3}$. Intent

Intentions account for 25\% of forest fire causes (Ministry of Agriculture, 2005) or for 29.3\% according to Kailidis and Karanikola (2004). This figure may, of course, be much higher if one considers that a significant proportion of unknown causes may be attributed to arson that has not been confirmed.

Regarding the causes of arson (intentional fires), these stem from many factors and are also assisted by many others.

a. Shepherds still consider fires as a means of foraging material amelioration, although the legislation of all Mediterranean countries prohibits the use of fire near forestlands.

b. Flammable forest material has increased 2-4 times when compared to that of 1974 (regime change) (Kailidis and Karanikola 2004). This is due to the fact that in many regions the countryside has been abandoned by young people in particular, also, the use of forest biomass waste for heating purposes has been replaced, in many areas, by burning petroleum (stoves and ovens that burn wood are rare in the Greek countryside) and the collection of resin is virtually abandoned, thus, resin forests have gradually lost their old means of protection.

The tendency of abandonment of mountain regions by people living near forests who were concerned about forests as, among other things, they were a source of income, worsens the situation.

c. Political reasons or terrorist acts. Kailidis and Karanikola (2004) argue that fire outbreaks observed were associated with political events in the country (e.g. the catastrophe of Minor Asia, land occupation during wars, civil war and, during the last years, elections).

d. Land use conflicts on forest lands. The expansion of human intervention is particularly intense due to a high demand for urban uses, holiday residences and tourist 
development. Trespassing, the illegal creation of building sites and land use changes are not directly made, but after degradation actions of forests and forestlands take place, such as fires. The regions suffering the greatest pressures are suburban or areas of holiday or tourist interest (e.g. island regions). This kind of pressures is based on legislative and administrative deficiencies concerning both forest protection and spatial planning. This has created extensive zones of mixing forest lands with settlements, resulting in an extremely high risk of fires, the destruction of forests, properties, as well as the loss of human lives. According to surveys, about $3 / 4$ of fire-ignition points lie in these zones and their majority is located in the type of zone characterized by high accumulation of vegetation and high density housing. So, in case of fire, it is selfevident that priority is given to protecting human life and property (Vélez, 2009). The issue of arbitrary construction in forested areas is particularly acute. Only in the County of Attica (around the capital) there are estimates for the existence of about 250,000 illegal constructions. Kailidis has mentioned that while in lowland and island areas a decline in forestlands favoring other land uses is observed, in mountain areas, due to their abandonment, forests are expanding since forest vegetation is introduced in abandoned fields.

e. Complex proprietary regime. The lack of forest maps and forest cadastre (the first three forest maps in the country were formed in the spring of 2011 and concern Attica, while the Ministry of Environment, Energy and Climate Change has initiated the issue of forest maps for the whole country) is causing continuous controversy about the status of the land (forest or non-forest), conflicts between the Forest Service and the public, time-consuming administrative procedures regarding the designation of lands, and, finally, their non effective protection. In Greece, the rebuttable presumption that the owner of the land is the state applies to forests and forestlands. That is, lands with forest vegetation belong to the public, unless their claimers can prove their ownership with an administrative recognition or a definitive decision by accord. The above explain the conflicts between the public and the forest service and the huge delays in resolving property disputes.

The above mentioned forest fire causes are also determined by several factors such as meteorological conditions (air temperature, wind intensity and speed, moisture content of forest flammable matter), type and quantity of the flammable matter, topography (altitude, exposure and slope), accessibility of the area, means available to extinguish the fire, the start time of the fire, season (most fires occur during the summer months and in the time period from 12 to 15 o'clock) and the response time to start extinguishing it. It is worth noting that wind speed is considered by Smith (2002), as the main factor for fire initiation. Dry and warm conditions characterizing summer months in Mediterranean regions, promote the outburst, and the easy spread of forest fires.

Other factors contributing to the phenomenon of forest fires in Greece is the fact that greater emphasis is given on fire suppression and not fire prevention, inappropriate vegetation control (management), insufficient involvement of the public and volunteers and also insufficient public information / education (WWF, 2010).

\subsubsection{Protection against fire}

Various bodies with, to an extent, interrelated responsibilities get involved in the protection of Greek forests and forest land. These bodies include (WWF, 2010): the Forest Service, the Fire Service, the General Secretariat for Civil Protection, Organizations of Local 
Government, Management Bodies of Protected Areas, General Directorate of Forestry, Greek Police Force, the Ministry of Foreign Affairs, Volunteers and Nonprofit Organizations. Examples included: the Forest Service is responsible for the fire prevention (e.g., maintenance of forest road networks, thinning vegetation, cleaning fire lane, preparation for fire suppression (e.g. patrols) and ecosystem restoration (burnt area mapping, issuing reforestation acts where protection and restoration of burned forests is necessary). The Fire Department is responsible for the suppression preparations (e.g. organization of fire lookout stations, recruitment and distribution of seasonal staff, training staff and volunteers) and the suppression (fire extinction, watch over for fire reactivation). The Managing Bodies of Protected Areas are responsible for the preparation of management plans for the areas and the design and implementation of measures of protection and restoration of burnt protected areas, the General Secretariat for Civil Protection is aiming, amongst others, to draw a map of fire risk and the declaration of areas in a state of emergency. The daily risk prediction bulletin is an important tool in preventing forest fires in which the development of an indicator system has been adopted methodologically, with its prevailing approach being the one followed by the American fire risk assessment systems (United States - NFDRS and Canada - NFFDRS) adapted to the specificities of our country. The main goal of fire risk determination systems is the ability of presenting forecasts in the form of thematic maps presenting the risk as it has been assessed in the different geographic departments of the country. The fire risk map is usually composed in digital form and can be upgraded at regular intervals (daily during fire season) and depicts five risk levels as estimated in the various departments of the country. This measure leads to the immediate adoption of additional measures of prevention, alertness of the bodies involved in fighting forest fires and to avoid unnecessary alerts. The preparation of the map gets finished at 12:30 on the previous day of its application. Immediately after its compilation, the map becomes available, in minimum time, by the website of the General Secretariat for Civil Protection (www.civilprotection.gr), where all relevant bodies, volunteer fire squads, as well as all interested citizens can be informed (General Secretariat for Civil Protection).

\subsubsection{Statistics}

According to Dimitrakopoulos (2001), who analyzed fires in forests and woodlands during the period 1955-1999, the average annual burnt areas were rising exponentially every decade, thus, in the 80 s they increased five times compared to the $50 \mathrm{~s}$, whereas in the $90 \mathrm{~s}$, there was a relative decline when compared to the $80 \mathrm{~s}$. Overall, while the number of fires has nearly doubled in the ' 80 s and the ' 90 s when compared to the '60s and '70s, the burned areas almost tripled.

The phenomenon of forest fires as evolving from the beginning of the last decade is demonstrated in Table 5 (Ministry of Environment, Energy and Climate Change / General Directorate for Development and Protection of Forests and Natural Environment, 2010).

As observed in table 5, the percentage of unknown causes is very high as it fluctuates between $41 \%$ and $91.5 \%$ (for the years 2005-2008 we have no definitive data regarding the causes). There is a great chance that human causes are a part of these unknown causes. Outbreaks occur not on the number of fires, but the size of the area burned. According to Kailidi and Karanikolas (2004) and Dimitrakopoulos (2001), in general, concerning the period 1980-2000, outbreaks concern the years 1985 (elections), 1988 (drought, political excerbation), 1998 (the year in which extinguishing forest fires came under the provision of the Fire Service rather than the Forest Service that was responsible until then by an act of 
law) and 2000. According to table 5, the year 2007 was particularly devastating for Greece with regard to fires. Extensive fires in many parts of the country (mainly in August), burned more than 200,000 Ha of land. At least 63 people died, 1,500 houses got burned leaving 6,000 homeless. Also, 4.5 million trees, 60,000 sheep and thousands of swarms of bees got burned. Seven "Natura 2000 " areas, burned down by $16.3 \%$ to $50.4 \%$. The areas affected were in the Peloponnese, the island of Euboea and Central Greece (Attica and Fthiotida counties). The cost of the disaster reached 5 billion euros.

\begin{tabular}{|c|c|c|c|c|c|c|c|}
\hline YEAR & $\begin{array}{c}\text { TOTAL } \\
\text { NUMBER } \\
\text { OF FIRES }\end{array}$ & $\begin{array}{c}\text { TOTAL } \\
\text { BURNT } \\
\text { LAND } \\
\text { (Ha) }\end{array}$ & $\begin{array}{c}\text { TOTAL } \\
\text { BURNT } \\
\text { FORESTS } \\
\text { (Ha) }\end{array}$ & $\begin{array}{c}\text { BURNT } \\
\text { WOODED } \\
\text { LAND } \\
\text { (Ha) }\end{array}$ & $\begin{array}{c}\text { HUMAN } \\
\text { CAUSES }\end{array}$ & $\begin{array}{c}\text { NATURAL } \\
\text { CAUSES }\end{array}$ & $\begin{array}{c}\text { UNKNOWN } \\
\text { CAUSES }\end{array}$ \\
\hline 1990 & 1,322 & 38,593 & 21,088 & 17,505 & 48.60 & 3,32 & 48.08 \\
\hline 1991 & 941 & 23,574 & 8,000 & 15,574 & 57.27 & 1.91 & 40.81 \\
\hline 1992 & 2,042 & 66,347 & 23,194 & 43,153 & 42.51 & 2.98 & 54.50 \\
\hline 1993 & 2,406 & 54,049 & 24,200 & 29,849 & 42.50 & 2.53 & 54.96 \\
\hline 1994 & 1,954 & 52,603 & 23,392 & 29,211 & 39.15 & 4.91 & 55.93 \\
\hline 1995 & 1,493 & 19,177 & 9,035 & 10,142 & 36.10 & 3.95 & 59.94 \\
\hline 1996 & 1,527 & 22,990 & 8,111 & 14,879 & 29.60 & 3.27 & 67.12 \\
\hline 1997 & 2,273 & 34,781 & 16,119 & 18,662 & 35.41 & 2.37 & 62.22 \\
\hline 1998 & 1,842 & 92,901 & 46,077 & 46,824 & 11.45 & 2.50 & 86.05 \\
\hline 1999 & 1,486 & 8,289 & 4,773 & 3,516 & 8.54 & 8.71 & 91.46 \\
\hline Mean & $\mathbf{1 , 7 2 8 . 6}$ & $\mathbf{4 1 , 3 3 0 . 4}$ & $\mathbf{1 8 , 3 9 8}$ & $\mathbf{2 2 , 9 3 1 . 5}$ & 33.60 & 3.21 & 63.19 \\
\hline 2000 & 2,581 & 145,034 & 69,579 & 75,455 & 13.01 & 4.99 & 81.99 \\
\hline 2001 & 2,658 & 18,342 & 8,423 & 9,929 & 15.24 & 6.66 & 78.10 \\
\hline 2002 & 1,400 & 4,337 & 887 & 3,450 & 10.00 & 11.0 & 79.00 \\
\hline 2003 & 1,425 & 3,263 & 960 & 2,303 & 11.01 & 16.21 & 72.77 \\
\hline 2004 & 1,755 & $10,722.1$ & 2,586 & $8,136.1$ & & & \\
\hline 2005 & 1,544 & $6,437.4$ & 2,180 & $4,257.2$ & & & \\
\hline 2006 & 1,417 & $12,661.4$ & 6,513 & $6,148.3$ & & & \\
\hline 2007 & 1,992 & 222,894 & $85,970.6$ & $136,923.4$ & & & \\
\hline 2008 & 1,486 & 29,172 & 13,397 & 15,775 & & & \\
\hline Mean & $\mathbf{1 , 8 0 6 . 4}$ & $\mathbf{5 0 , 3 1 8 . 1}$ & $\mathbf{2 1 , 1 6 6 . 2}$ & $\mathbf{2 9 , 1 5 3}$ & $\mathbf{1 4 . 3 6}$ & $\mathbf{9 . 7 0}$ & $\mathbf{7 5 . 9 3}$ \\
\hline
\end{tabular}

Table 5. Number of fires and burned area in Ha during the period 1990-2008

After the fire, recording of burnt areas of forest character of the Greek Territory takes place using high resolution satellite images with the cooperation of ESA (European Space Company) and the National Observatory of Athens. The mapping provides information about the overall expanse and magnitude of the damages of burnt areas and supports procedures for the recovery of the burned areas.

\section{Reforestation / afforestation in Greece}

As mentioned previously, after the fire, the Forest Department (or the Management Authority in the case of Protected Areas) is responsible for further protecting and restoring the area burned. 
Rehabilitation / protection actions begin immediately and generally (differ according to case) may include: a) Anti-erosion works: avoiding tillage, prohibition of any kind of grazing in order to facilitate the development and regeneration of vegetation burned, antierosive construction projects in streams and gorges to slow down the flow of flood waters, placing branch-meshes, trunk-meshes, construction of small dams on streams, b) Projects for slope formation and protection, c) Reforestations: When the burnt area includes maquis forests or Mediterranean conifer forests (e.g. Pinus halepensis and Pinus pinea), they can be recreated in a few years. The Forest Service takes into account the type of vegetation that has been burned, the success potential of natural regeneration of trees and the general conditions (e.g. slope), and, accordingly, shall proceed, or not, to artificial reforestation of burnt areas using native species.

Reforestations, being a duty of the Forest Service of Greece, are not limited to the post-fire period.

The purpose of reforestation is the creation of new forests, the renewal of mature forests and the recovery of degraded forest ecosystems while ensuring natural regeneration or artificial intervention (seeding or planting) for production purposes and the protection of soils. There are also hydrologic purposes, as well as environmental and aesthetic purposes.

On average, over the past 5 years, approximately 1.000 Ha of land have been reforested. Last year (2010), a very ambitious program has started that predicts only for the Attica Prefecture (the county in which the country's capital is located), reforestations of 10,000 Ha by 2014 . This program concerns areas that have been burnt 2 or 3 times and, therefore, can not be naturally regenerated. Especially in the Attica region, according to data from the Ministry of Environment, Energy and Climate Change (2010) (see Table 7), the cost of reforestation in the last 8 years was enormous. However, it should be noted that the costs of Reforestation projects in Attica, also included, maintaining and improving existing roads and the creation and maintenance of fencing.

\begin{tabular}{|c|c|c|c|}
\hline Year & $\begin{array}{c}\text { Reforestations } \\
\mathbf{( H a )}\end{array}$ & $\begin{array}{c}\text { Planted saplings } \\
\text { (thousands) }\end{array}$ & $\begin{array}{c}\text { Incurred Expenditure } \\
(\boldsymbol{(})\end{array}$ \\
\hline $1941-1950$ & $24,706.1$ & 40,978 & 36,616 \\
\hline $1951-1960$ & $54,353.1$ & 104,055 & 340,461 \\
\hline $1961-1970$ & $36,613.2$ & 103,265 & 865,010 \\
\hline $1971-1980$ & $41,682.0$ & 90,098 & $3,273,843$ \\
\hline $1981-1990$ & $72,796.0$ & 71,403 & $34,583,941$ \\
\hline $1991-2000$ & $31,408.6$ & 47,226 & $68,658,711$ \\
\hline $2001-2007$ & $9,234.4$ & 9,509 & $18,218,804$ \\
\hline
\end{tabular}

Table 6. Realized reforestation projects and incurred expenditure from the start of the action until 2007 


\begin{tabular}{|c|c|c|c|c|c|}
\hline Year & $\begin{array}{c}\text { Reforested } \\
\text { land (Ha) }\end{array}$ & $\begin{array}{c}\text { Planted } \\
\text { saplings } \\
(\mathrm{No})\end{array}$ & $\begin{array}{c}\text { Seed } \\
\text { Plantations } \\
(\mathrm{No})\end{array}$ & $\begin{array}{c}\text { Road } \\
\text { openings } \\
(\mathrm{km})\end{array}$ & $\begin{array}{c}\text { Expenditure } \\
\text { current prices }\end{array}$ \\
\hline $1976-1982$ & $5,481.1$ & $3,154,480$ & 159,102 & 234.67 & 130 \\
\hline $1983-1990$ & $2,546.9$ & $1,746,650$ & 88,470 & 82.43 & 7,622 \\
\hline $1991-2000$ & $3,533.5$ & $1,991,745$ & 93,100 & 46.68 & 14,702 \\
\hline Total 1976-2000 & $\mathbf{1 1 , 5 6 1 . 5}$ & $\mathbf{6 , 8 9 2 , 8 7 5}$ & $\mathbf{3 4 0 , 6 7 2}$ & $\mathbf{3 6 3 . 7 7}$ & $\mathbf{2 2 , 4 5 3}$ \\
\hline $2001-2008$ & 1,361 & 912,704 & 0 & 2.93 & $4,654,000$ \\
\hline
\end{tabular}

Table 7. Reforestation projects in Attica

Apart from reforestations, under the Common Agricultural Policy (CAP), the measure of afforestation of agricultural land is being implemented since 1992 (Reg. 2080/1992 and Reg. 1257/99). According to this measure, owners of marginal productivity agricultural land are encouraged to transform it into forest land by planting forest tree species. This way, the afforested area in the EU (and Greece) increases with favorable consequences on global warming and on increasing biodiversity, slopes become effectively protected and nonproductive lands get withdrawn from production. Beneficiaries of this measure, receive subsidizes to cover planting and maintenance costs for up to 5 years after planting tree species, support for the construction of windbreaks, fire lanes and an annual support payment per hectare afforested (up to 20 years) to cover income losses resulting from land use change (Christopoulou, 2001).

In Greece, the implementation of Regulation EEC/2080/92 from 1993 to 2001 resulted in the establishment of 35,840 Ha of forest plantations mainly of Robinia pseudoacacia L (black locust), Populus sp (poplar) and Juglans regia (walnut) (Arabatzis et al., 2006, Chalikias and Christopoulou., 2010 ).

\section{Conclusions - proposals}

From the preceded analysis, it can be concluded that regarding Greece an increase of forest area in mountainous regions has been observed and an expansion of forest vegetation due to the cessation of farming activities, whereas in areas around urban centers (mainly around the capital), in islands or areas of a tourist interest, a significant decline in forest vegetation can be observed. The great frequency of forest fires, overgrazing, the scattered and out of city plan building and creation of traffic infrastructures are the main causes of deforestation in Greece. The lack of forest maps and cadastre is an important factor contributing to deforestation, as it favors tresspassing and illegal housing development of woodlands and the creation of arbitrary structures within them. This phenomenon is naturally based on legislative and administrative deficiencies relating to both forest protection and spatial planning. Thus, extensive areas of mixing forests with residential areas have been created, where the most frequent and most destructive fires occur. In the spring of 2011 the first 3 maps were posted and are now in the process of submitting complaints concerning the status of lands (forest or not) aiming to create forest maps and a forest cadastre for the entire country (already maps are being 
prepared for 107 regions corresponding to 190,000 Ha), in order to resolve the complex ownership regime regarding forestlands in Greece and lead us to efficient spatial planning and effective environmental and forest policy.

Regarding policies to increase forest area, they focus on reforestations materiazed by the Forest Service, and the implementation of the EU Regulation on afforestation of marginal agricultural land.

Finally, for the protection of forest ecosystems in general as well as, specifically, in order to protect them from their main enemies (grazing, fire and subsequent change of use), the implementation of the following is necessary:

- $\quad$ Rapid composition of forest maps for the entire country

- Application of contemporary standards regarding the compilation of management plans on forests, which should take into account, the productive functions of forests (sustainability of yields) the protective, ecological and social functions (multifunctional forest management, sustainable management of forest ecosystems), as well as new data on climate change. The state should strengthen the forest sector, both materially and with the necessary personnel, given that, according to science experts, public forests managed for a long time with high quality management plans, are currently being managed with logging plans due to lack of funds and personnel.

- Creation of management plans by the Management Bodies of Protected Areas.

- Conversion of all managed coppice forests in the country, especially oak forests, not only to achieve higher timber stock, but also for ecological / environmental reasons (more effective soil protection, increase of biodiversity, landscape aesthetics, the hydrological role of forests etc.).

- Greater emphasis on the prevention of forest fires, through managing tree clusters and dead biomass.

- Emphasis on public information - awareness regarding the multidimensional functions of forests, as well as the impacts of fires in nature, climate and public health. Awareness of local authorities and organizing locals into voluntary groups aiming for fire prevention, suppression and reforestation, coordinated by the Forest Service.

- Integrated management of burned areas.

- Rigidity regarding compliance with the ban on grazing in burnt forest areas, in accordance with legislation, while ensuring alternative sources of food for animals, the composition and implementation of management plans for pasturelands and compliance with the carrying capacity of rangelands.

- Rigidity regarding the observance of the legislation concerning the protection of burnt areas and specifically the issue of land use change.

- Strict compliance with the use of native species, well adapted to the particularities of each region, during reforestation.

- Logging and wood transport should take place in a manner that causes no damage to the ecosystem and its regeneration.

- Taking into account that Forest Service officials have scientific knowledge on the physiology of forests and wild areas and are well aware of the area for which they are responsible, it would be advisable that the responsibility of suppressing forest fires should be assigned to the Forest Service.

Particular attention, sparingness and skepticism regarding the opening up of a dense road network in forests. 


\section{Acknowledgment}

I would like to thank my collaborator Ms Kaisari, for her assistance in translating and editing this chapter.

\section{References}

Arabatzis G. ; Christopoulou, O. \& Soutsas, K. (2006). The EEC Regulation 2080/92 “about forest measures in agriculture" in Greece: The case of poplar plantations. International Journal of Ecodynamics . Vol.1, No.3, pp. 1-13. ISSN: 1743-5242

Beriatos, E. (2002). Peri-urban forests, green walls of Greek cities: protection and promotion opportunities. University of Thessaly, Department of Planning and Regional Development, Discussion Paper Series, Vol.8, No.14, pp. 343-354 (in greek)

Chalikias, M. \& Christopoulou, O. (2010). Factors affecting the Forest Plantations Establishment in the Frame of the Common Agricultural Policy. Journal of Environmental Protection and Ecology (JEPE), Vol. 11, (forthcoming). ISSN: 1311-5065.

Chomitz, K.M. \& Gray, D.A.(1996). Roads, land use and deforestation: a spatial model applied to Belize. World Bank Economic Review, Vol.10, No.3, pp. 487-512. ISSN: 1564-698X

Christopoulou, O.; Polyzos, S. \& Minetos, D. (2007). Peri-urban and Urban Forests in Greece: Obstacle or Advantage to Urban Development? Management of Environmental Quality: An International Journal, Vol.18, No.4, pp. 382-395. ISSN: 1477-7835

Christopoulou, O. (2001). Institutional Framework for the Protection of European Forests. Environment and Law. Vol.17, pp. 366-375 (in greek). ISSN: 1108-2747

Dimitrakopoulos, A.P. (2001). Temporal analysis of forest fires and burnt forest land during the time period 1955-1999. Proceedings of the 9th Panhellenic Forest Conference "Natural Environment Protection and Restoration of Disturbed Areas", pp. $85-90$ (in greek). ISSN: 960-87107-0-7

Eurostat, 2009. Forestry Statistics, pp.174. ISBN: 978-92-79-13111-0.

Eurostat, (2010). Environmental Statistics and accounts in Europe. pp. 346

FAO, (2005). Global Forest Ressources Assessment. Main report.

FAO, (2010). Global Forest Ressources Assessment. Main report. . pp. 378

Geist, H. \& Lambin, E. (2001). What drives tropical deforestation? A meta-analysis of proximate and underlying causes of deforestation based on subnational case study evidence; in LUCC Report Series, No.4

Greek Committee for Combating Desertification, (2000). Greek Draft Action Plan against Desertification, Ministry of Agriculture, National Agricultural Research Foundation, National Observatory of Athens, UNCED, pp. 142 (in greek)

Greek Parliament, (2003). (Preamble) Explanatory Report on the Law 3208/2003, Athens

Kailidis, D. \& Karanikola, P., (2004). Forest fires 1900-2000. Giachoudi Publications, Thessaloniki, pp. 434 (in greek). ISBN: 960-7425-83-9

Kaimowitz, D. \& Angelsen, A. (1998). Economic Models of Tropical Deforestation: A review. Centre for International Forestry Research -CIFOR, Bogor, Indonesia, 153 pp.

Kotoulas, D.; Dafis, S. \& Stergiadis, G. (eds.) (1989). Greek Forests. Goulandri Museum of Natural History. 91 pp (in greek)

Lambin, E.F.; Turner, B.L.; Geist, H.J.; Agbola, S.B.; Angelsen, A.; Bruce, J.W.; Coomes, O.T.; Dirzo, R.; Fischer, G. \& Folke, C. (2001). The causes of land-use and land-cover 
change:moving beyond the myths. Global Environmental Change Vol.11, No.4, pp. 261. ISSN: 0959-3780

Le Houerou, H.N. (1981). Impact of man and his animals on Mediterranean vegetation. In Mediterranean Type Ecosystems, F.di Castri et al. (eds.), Elsevier Scientific Co., Amsterdam. pp. 479-521

Margaris, N.S. \& Koutsidou, E. (1998). Fires and overgrazing: the main driving forces of desertification in the Aegean islands. In: Ecological Basis for Livestock Grazing in Mediterranean Ecosystems. Papanastasis, V.P. \& Peter, D. (eds.), European Commission, EUR 1830N, Luxemburg, pp. 167-170

Minetos, D. (2009). Recent changes in land use in Greece and their impact on sustainable rural development: A theoretical and empirical investigation. PhD Thesis, University of Thessaly, pp. 551 (in greek)

Minetos, D. \& Polyzos, S. (2010). Deforestation processes in Greece: A spatial analysis by using an ordinal regression model. Forest Policy and Economics, Vol.12, pp. 457-472. ISSN: 1389-9341

Oikonomou, A.; Michopoulos, P.; Skouteri, A. \& Bourletsikas, A. (2004). 1988-2002: 15 years of monitoring the phyto-sanitary condition of Greek forests. Edition of the Institute of Mediterranean Forest Ecosystems and Forest Products Technology, NAGREF, Vol.17, pp. 99-110 (in greek)

Papanastasis, V. (1990). Pastoral and forage systems in Greece. 6th Meeting FAO Subnetwork on Mediterranean Pastures and Fodder Crops, Bari, Italy. pp. 177-180

Papanastasis, V.P. (1998). Grazing intensity as an index of degradation in semi-natural ecosystems: the case of Psilorites mountain in Crete, In: Indicators for Assessing Desertification in the Mediterranean. Nucleo Ricerca Desertificatione, G. Enne, M. D' Angelo and C. Zanolla, (eds.), Universitá di Sassari. Italy, pp.146-158

Papanastasis, V.P. (2000). Land degradation caused by overgrazing and wildfires and management strategies to prevent and mitigate their effects. In: Desertification in Europe: mitigation strategies, land-use planning, G. Enne, Ch. Zanolla and D. Peter (eds.), European Commission, EUR 19390, Luxembourg, pp. 187-198

Papanastasis, V. (2008). Livestock grazing and rangelands. Lucinda. Land Care in Desertification Affected Areas. From Science Towards Application. Booklets Series: C, No.5, 17 pp.

Pearce, D.W. (2001). The economic value of forest ecosystems. CSERGE-Economics, University College London, London, UK. Blakwell Science, Inc.

Rizos, S. (2004). Spatial Planning and Forest in Germany. Environment and Law, Vol.3 pp. 317-321 (in greek). ISSN: 1108-2747

Smith, K. (2002). Environmental hazards: assessing risk and reducing disaster. $3^{\text {rd }}$ ed. Routledge, London and New York. Taylor and Francis group, $392 \mathrm{pp}$.

Tambakis, S. \& Karanikola, P. (2002). Forest fires and volunteering as a means to address them. Proceedings of the 10th Panhellenic Forestry Congress "Research, Protection and Management of Terrestrial Ecosystems, Peri-urban Forests and Urban green", pp. 723-730 (in greek). ISSN: 1109-7574

Vélez, R. (2009). Challenge Factors: Focusing on economic and social causes. In: Our life with Forest Fires. A contribution to the science-politics dialog, Birot Y. (ed.), European Forest Institute, Discussion Paper, Vol.15, pp. 24-48. ISBN: 978-952-5453-50-8 
Verburg, P.H.; Schulp, C.J.E.; Witte, N. \& Veldkamp, A. (2006). Downscaling of land use change scenarios to assess the dynamics of European landscapes. Agriculture, Ecosystems \& Environment, Vol.114, No.1, pp. 39-56. ISSN: 0167-8809

WWF, (2010). The uncertain future of Greek forests. Results and suggestions from the WWF Hellas program "The Future of Forests", Athens, 30 pp.

Xanthopoulos, G. (1998). Forest fires in Greece. Past, present and future. Epikentra, pp. 62-71 (in greek)

Zagas, Th.; Tsitsoni, Th.; Ganatsas, P. \& Chatzistathis, A. (2004). Impacts of forest fires on forest vegetation. Proceedings of the $8^{\text {th }}$ National Conference of the Greek Forestry Society "Modern Problems of Forestry", pp. 87-92 (in greek) 


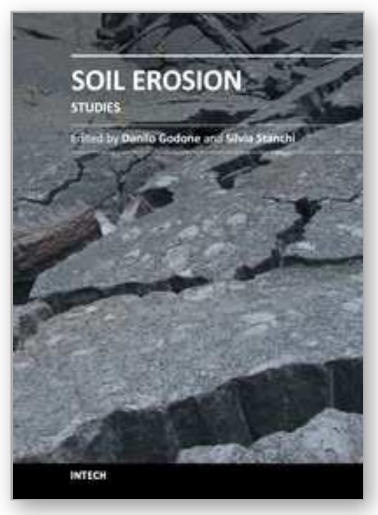

\author{
Soil Erosion Studies \\ Edited by Dr. Danilo Godone
}

ISBN 978-953-307-710-9

Hard cover, 320 pages

Publisher InTech

Published online 21, November, 2011

Published in print edition November, 2011

Soil erosion affects a large part of the Earth surface, and accelerated soil erosion is recognized as one of the main soil threats, compromising soil productive and protective functions. The land management in areas affected by soil erosion is a relevant issue for landscape and ecosystems preservation. In this book we collected a series of papers on erosion, not focusing on agronomic implications, but on a variety of other relevant aspects of the erosion phenomena. The book is divided into three sections: i) various implications of land management in arid and semiarid ecosystems, ii) erosion modeling and experimental studies; iii) other applications (e.g. geoscience, engineering). The book covers a wide range of erosion-related themes from a variety of points of view (assessment, modeling, mitigation, best practices etc.).

\title{
How to reference
}

In order to correctly reference this scholarly work, feel free to copy and paste the following:

Olga G. Christopoulou (2011). Deforestation / Reforestation in Mediterranean Europe: The Case of Greece, Soil Erosion Studies, Dr. Danilo Godone (Ed.), ISBN: 978-953-307-710-9, InTech, Available from: http://www.intechopen.com/books/soil-erosion-studies/deforestation-reforestation-in-mediterranean-europethe-case-of-greece

\section{INTECH}

open science | open minds

\section{InTech Europe}

University Campus STeP Ri

Slavka Krautzeka 83/A

51000 Rijeka, Croatia

Phone: +385 (51) 770447

Fax: +385 (51) 686166

www.intechopen.com

\section{InTech China}

Unit 405, Office Block, Hotel Equatorial Shanghai

No.65, Yan An Road (West), Shanghai, 200040, China

中国上海市延安西路65号上海国际贵都大饭店办公楼405单元

Phone: +86-21-62489820

Fax: $+86-21-62489821$ 
(C) 2011 The Author(s). Licensee IntechOpen. This is an open access article distributed under the terms of the Creative Commons Attribution 3.0 License, which permits unrestricted use, distribution, and reproduction in any medium, provided the original work is properly cited. 